\title{
Element composition of solid airborne particles deposited in snow in the vicinity of gas-fired heating plant
}

\author{
Anna V. Talovskaya*, Egor G. Yazikov, Ekaterina A. Filimonenko, Natalia P. Samokhina, Tatyana \\ S. Shakhova, Irina A. Parygina
}

Tomsk Polytechnic University, 30 Lenin Avenue, Tomsk, Russia, 634050

\begin{abstract}
Local heating plants are the main pollution source of rural areas. Currently, there are few studies on the composition of local heating plants emissions. The article deals with the research results of air pollution level with solid airborne particles in the vicinity of local gas-fired heating plants of some districts of Tomsk region. The snow sampling was conducted for the purpose of solid airborne particles extraction from snow cover. The content of 28 chemical elements (heavy metals, rare earth and radioactive elements, aurum, argentum, bromine) in the samples was detected using instrumental neutron activation analysis. The mercury content was determined by the flameless atomic absorption. The results have shown that the dust load value corresponds to low pollution level and 3,5 times exceeds the background value. It was detected, the content of studied elements exceeds the baseline data, and level of pollution with these elements corresponds to the average pollution level. It is suggested, the income of solid airborne particles containing these elements is connected both with emission of gas-fired heating plant, and local and trans-border sources.
\end{abstract}

Keywords: gas-fired heating plant, snow, solid airborne particles, dust load, trace elements

\section{INTRODUCTION}

Solid airborne particles suspended in the atmosphere comprise a complex of different elements and compounds. They can be arising from natural sources such as windborne dust, sea spray, and volcanoes. These particles are also released from many different anthropogenic sources such as industry, combustion of fossil fuels, traffic emissions, and energy production. Solid airborne particles play an important role in the urban environment. Pollution of the environment with anthropogenic solid airborne particles is an ever increasing global problem [1]. Study of the properties and composition of solid airborne particles, including anthropogenic fraction is of great importance for the problems of ecology, climatology, atmospheric physics and chemistry [2].

The objects of fuel and energy complex (heating plants, thermal power plants) are one of the main sources of solid airborne particles in the industrial and urban centers and rural areas. The objects of fuel and energy complex are often located directly in the residential areas, and therefore, their emissions constitute a hazard for human health [3]. The geochemical peculiarity of solid airborne particles is their ability to condense chemical elements on their surface, including toxic for human health elements. Wehner and Wiedensohler (1999) [4] showed that the stationary combustion of natural gas emitted very low number of particles, much less than the combustion of oil. Among thermal engineering emissions of enterprises, the dominating ones are the emissions from power facilities, where coal is used. That is why, currently, a great attention is paid to estimation of the role of coal-fired power emission of plants for forming of aerial environment compound and emissions influence on the human health [5]. In present time, there are a few researches on chemical compound and morphological characteristics of solid particles emitted from enterprises of heat power industry, where other kinds of fuel materials such natural gas, oil and wood are used.

In the territory of Tomsk region, the fuel and energy enterprises are situated, where different kinds of fuel materials (coal, gas, fuel oil) and biofuel (wood) are used, which is a distinctive feature of the region in comparison with other Siberian regions [6].

*talovskaj@yandex.ru; phone +7 96278509 49; fax +7 3822418910

22nd International Symposium Atmospheric and Ocean Optics: Atmospheric Physics, edited by

Gennadii G. Matvienko, Oleg A. Romanovskii, Proc. of SPIE Vol. 10035, 100354F

(C) 2016 SPIE · CCC code: $0277-786 X / 16 / \$ 18 \cdot$ doi: $10.1117 / 12.2249309$ 
Gas infrastructure development of Tomsk region is one of the priority projects of regional government. In this perspective, there is a need for environmental assessment of gas-fired heating plants activity to estimate the emissions content and impact degree on the residential areas. By the assessment of gas-fired heating plants emissions, the main attention is paid to investigation of polycyclic aromatic hydrocarbons and gaseous combustion products; the issue of chemical compound of emitted solid particles influenced on the human health is insufficiently studied. For successful solution of ecological issues, it is necessary to have knowledge a wide range of emissions into the atmosphere. In winter period the mass of burning fuel reaches to its maximum, and emitted solid particles settle on the snow cover in the result of dry and wet deposition, and that creates a particular technogenic load on the vicinity areas. Currently, the use of snow cover as a plate-accumulator for pollutants from the atmosphere is rather urgent [3, 6-10].

The present study of solid airborne particles deposited in snow was carried out in the vicinity of gas-fired heating plants locating in rural areas of Tomsk region. The main objectives of the present study were to (a) identify level of dust load, (b) determine element concentration, (c) evaluate contamination level with elements (heavy metals, rare-earth and radioactive elements).

\section{METHODS}

At the end of winter period the snow sampling was conducted at the distance of 70-120 meters from gas-fired heating plants located in the territory of Shegarsky and Kozhevnikovsky administrative districts of Tomsk region. Snow samples were collected and prepared according to standard methods [7,11]. Sampling points were chosen based on the prevailing wind direction in Tomsk region (southern, south-western). Snow was sampled from the area of $0,25 \mathrm{~m}^{2}$, from the average depth of $55 \mathrm{~cm}$. The samples were put and transported in the plastic bags. I the laboratory, the samples were melt at room temperature. Then clear water was poured out, and snowmelt water residue with solid particles was filtered. Obtained insoluble fraction of aerosol was sieved (with opening of $1 \mathrm{~mm}$ ) and weighted. Then, insoluble fraction of aerosol was investigated for content of 28 elements using instrumental neutron-activation analysis (INAA) in the accredited nucleargeochemical laboratory of the Department of Geoecology and Geochemistry of TPU. The samples were also analyzed by the method of flameless atomic absorption spectrometry for mercury content in research laboratory of trace element analysis in this center. The research results were used for calculation of dust load $\left(\mathrm{P}_{\mathrm{n}}\right.$, in $\left.\mathrm{mg} \cdot\left(\mathrm{m}^{2} \cdot \text { day }\right)^{-1}\right)$, daily average deposition of trace element to snow cover $\left(D_{i}, \mathrm{mg} \cdot\left(\mathrm{km}^{2} \cdot \mathrm{day}\right)^{-1}\right)$, total pollution factor $Z_{d}$, concentration coefficient of elements[7, 11], enrichment factor of elements [12]. Background concentration of elements in the insoluble fraction of aerosol in snow is according to [13], and of mercury according to [12].

\section{RESULTS AND DISCUSSION}

The data analysis has shown that the dust load value changed from 6,5 to 52,1 by the average value of $25,0 \mathrm{mg} \cdot\left(\mathrm{m}^{2} \cdot\right.$ day) ${ }^{1}$, the average value for Tomsk region $11,0 \mathrm{mg} \cdot\left(\mathrm{m}^{2} \cdot \text { day }\right)^{-1}$ and baseline data of $7,0 \mathrm{mg} \cdot\left(\mathrm{m}^{2} \cdot \text { day }\right)^{-1}$ [12] (table). Maximal value of dust load $\left(52,1 \mathrm{mg} \cdot\left(\mathrm{m}^{2} \cdot \text { day }\right)^{-1}\right)$ was detected in the vicinity of two gas-fired heating plants in Kozhevnikovsky district. According to standard rating [7, 12], obtained dust load values correspond to low pollution degree. The dust load in the vicinity of studied heating plants is 1,3-2,7 times lower than the average value of dust load for the locality, where these plants are located. Wehner and Wiedensohler (1999) [4] have shown that the stationary combustion of natural gas emitted very low number of particles. These researches allow explaining the low level of dust load in the vicinity of studied gas-fired heating plants.

The calculation of total pollution factor has shown that this value is 113 , which corresponds to moderate pollution degree $[7,12]$. This pollution degree is determined by the high accumulation degree of $\mathrm{U}, \mathrm{As}, \mathrm{Yb}, \mathrm{Tb}, \mathrm{La}, \mathrm{Ba}, \mathrm{Sm}, \mathrm{Ta}$ in the samples compared with baseline data, so uranium content 27 times exceeds the background, the other mentioned elements exceed it from 7 to 12 times. $\mathrm{Ce}, \mathrm{Zn}, \mathrm{Lu}, \mathrm{Sr}, \mathrm{Br}, \mathrm{Na}, \mathrm{Th}, \mathrm{Hf}, \mathrm{Sb}, \mathrm{Nd}$ и $\mathrm{Hg}$ concentrationss from 2 to 5 times exceed the background. High concentration of uranium and a range of rare earth elements compared with baseline data were detected in the samples from the vicinity of gas-fired heating plant in Kozhevnikovsky district. Such excess can indicate the local source of these elements income. In snow cover the abnormal (more than 2 times exceeding the baseline data) contents of elements are determined. These elements are a part of emissions or compose the transformation products. The contents of $\mathrm{Sc}, \mathrm{Cr}, \mathrm{Cs}, \mathrm{Eu}, \mathrm{Rb}$ and $\mathrm{Au}$ are at the background level, it can indicate the regional or lithogenic sources. The calculation of enrichment factor have shown that $\mathrm{U}, \mathrm{Au}, \mathrm{Hf}, \mathrm{Ba}, \mathrm{As}, \mathrm{Zn}, \mathrm{Sb}$ and $\mathrm{Hg}$ are of anthropogenic origin, because the enrichment factor value changes from 2 to 16 , but other elements are connected with lithogenic or regional sources. In addition, the element composition of insoluble fraction of aerosol in snow near the 
gas-fired heating plants differs by lower concentrations of the investigating range of chemical elements in comparison with the average levels of their contents for the samples from locality, where they are situated.

The value of daily average deposition of trace element to snow cover in the vicinity of gas-fired heating plants from 2 to 40 exceeds the background data. By the background value excess, the values of daily average deposition of trace element to snow cover can be combined in the following groups: 2-10 background values $(\mathrm{Ca}, \mathrm{Th}, \mathrm{Cr}, \mathrm{Hf}, \mathrm{Nd}, \mathrm{Br}, \mathrm{Cs}, \mathrm{Sc}, \mathrm{Rb}$, $\mathrm{Fe}, \mathrm{Co}, \mathrm{Na}, \mathrm{Eu}, \mathrm{Sb}, \mathrm{Hg}$ ), 10-20 (Ce, La, Sr, Zn) and 20-40 (Sm, Yb, Ba, As, Tb, Ta, La). High value of daily average deposition of $U$ to snow cover $\left(334 \mathrm{mg} \cdot\left(\mathrm{km}^{2} \cdot \mathrm{day}\right)^{-1}\right.$ by the background of $\left.1,4 \mathrm{mg} \cdot\left(\mathrm{km}^{2} \cdot \mathrm{day}\right)^{-1}\right)$ was detected in the samples from the vicinity of gas-fired heating plants of Kozhevnikovsky district.

Table 1

The average value of concentration coefficient (CC) and enrichment factor (EFs) of chemical elements in the insoluble fraction of aerosol in snow cover in the vicinity of gas-fired heating plants of Tomsk region (Shegarsky and

Kozhevnikovsky administrative districts)

\begin{tabular}{|c|c|c|c|c|c|c|c|c|}
\hline $\begin{array}{l}\text { Chemical } \\
\text { element }\end{array}$ & $\mathrm{CC}$ & EFs & $\begin{array}{l}\text { Chemical } \\
\text { element }\end{array}$ & $\mathrm{CC}$ & EFs & $\begin{array}{l}\text { Chemical } \\
\text { element }\end{array}$ & $\mathrm{CC}$ & EFs \\
\hline $\mathrm{Na}$ & 2,7 & 0,4 & $\mathrm{Sr}$ & 3,2 & 2,0 & $\mathrm{Yb}$ & 11,4 & 1,5 \\
\hline $\mathrm{Ca}$ & 1,8 & 0,6 & $\mathrm{Sb}$ & 1,7 & 5,5 & $\mathrm{Lu}$ & 4,2 & 1,0 \\
\hline $\mathrm{Sc}$ & 1,3 & 1,0 & Cs & 0,9 & 1,3 & $\mathrm{Hf}$ & 2,1 & 1,7 \\
\hline $\mathrm{Cr}$ & 1,0 & 1,2 & $\mathrm{Ba}$ & 9,9 & 3,2 & $\mathrm{Ta}$ & 7,2 & 0,9 \\
\hline $\mathrm{Fe}$ & 1,5 & 1,2 & $\mathrm{La}$ & 10,1 & 1,5 & $\mathrm{Au}$ & 0,3 & 16,0 \\
\hline Co & 1,5 & 1,5 & $\mathrm{Ce}$ & 5,4 & 1,5 & $\mathrm{Hg}$ & 2,0 & 3,7 \\
\hline $\mathrm{Zn}$ & 4,8 & 14,3 & $\mathrm{Nd}$ & 1,6 & 1,3 & Th & 2,6 & 1,3 \\
\hline As & 12,2 & 1,6 & $\mathrm{Sm}$ & 7,5 & 1,2 & $\mathrm{U}$ & 27,1 & 3,6 \\
\hline $\mathrm{Br}$ & 2,7 & 1,2 & $\mathrm{Eu}$ & 0,9 & 1,2 & & & \\
\hline $\mathrm{Rb}$ & 0,7 & 0,6 & $\mathrm{~Tb}$ & 10,4 & 1,2 & & & \\
\hline
\end{tabular}

Previous researches have allowed distinguishing $\mathrm{Sb}, \mathrm{Br}$ and $\mathrm{Hg}$ as indicator elements in the samples of insoluble fraction of aerosol in snow in the impacted areas of flare facilities for natural gas burning in Tomsk Petrochemical Plant [14]. The Hg disengagement in technological processes by thermal utilization and burning of natural resources (coal, oil, gas etc.) is significant. The excess of background uranium and rare earth elements content in the samples collected in the vicinity of investigated gas-fired heating plants supposed to be connected with the use of some coal in the plants; the presence of oil and solid impurities in using gas is also possible. Besides, the income of investigated elements can be explained by additional sources - local and transborder ones. Under the local sources we mean the private housing, where coal can be used for heating. According to [15], in coal radioactive and rare earth elements contain as impurity; these elements sorb during the burning at the fine fractions of solid particles and come to the atmospheric air. Earlier we [16] detect high concentrations of U, Th and rare earth elements in the samples from the localities of Kozhevnikovsky district. It can be explained by the following facts: from the one hand, snow cover inherits the peculiarities of soil chemical elements which also contain these elements in the increased values [17], from the other hand, their transborder transfer from the Tomsk-Seversk industrial agglomeration and Novosibirsk region according to prevailing wind direction is possible. The flat topography of West Siberia and barometric gradient in the cold half-year period from South-southwest to West-north-west determine the development of sustainable south-western transfer covering the whole flat part. The researches of insoluble fraction of aerosol in snow from the area of the Tomsk-Seversk industrial agglomeration have also shown the increased concentrations of radioactive and rare earth elements in the samples $[17,18]$.

\section{CONCLUSION}

The research findings for the investigation of the vicinity of gas-fired heating plants have shown the low level of air pollution with solid particles, the average level of pollution with chemical elements containing in solid particles of snow. In the samples of insoluble fraction of aerosol in snow, the exceed of chemical element contents compared with background data was detected, but at the same time, the content of studied elements does not exceed the average value of these elements contents in the samples from the locality, where heating plants are situated. The income of elements in the solid particles compound can be connected both with the quality of used fuel, and with local and transborder sources. 


\section{ACKNOWLEDGMENTS}

This research was funded by Russian Foundation for Basic Research (16-45-700184p_a). The authors thank all participants for their assistance in the performance of neutron activation analysis in the laboratories of International Innovative Academic and Science Center "Uranium Geology” (Tomsk Polytechnic University, Russia).

\section{REFERENCES}

1. Bell, M.L., Holloway, T. "Global impacts of particulate matter air pollution," Proc. Environ Res Lett (2) 045026, (2007).

2. Belan, B.D., Kozlov, A.V., Simonenkov, D.V., Tolmachev, G.N., Tsaruk, V.V. "Aerosol number size distributions in the lower troposphere over a background region and megalopolis (Novosibirsk) on result of airborne sounding in 2011-2013," Proc. SPIE 9292, 929244 (2014).

3. Osipova, N.A., Filimonenko, K.A., Talovskaya, A.V., Yazikov, E.G. "Geochemical Approach to Human Health Risk Assessment of Inhaled Trace Elements in the Vicinity of Industrial Enterprises in Tomsk, Russia," Human and Ecological Risk Assessment 21 (6), 1664-1685 (2015).

4. Wehner, B., Wiedensohler, A. "Aerosol characterization of a natural gas and oil-fired heating plant," Journal Aerosol Science 30 (1), 113-114 (1999).

5. Mohd Din, S.A., Nik Yahya, N.N.H., Hanapi, N., Abdullah, A. "Coal-fired power plant airborne particles impact towards human health," Jurnal Teknologi 77 (30), 19-24 (2015).

6. Viklander, M. "Substances in Urban Snow. A comparison of the contamination of snow in different parts of the city of Lulea, Sweden," Water Air Soil Poll 114 (3-4), 377-394 (1999).

7. Baltrenaite, E., Baltrenas, P., Lietuvninkas, A., Sereviciene, V., Zuokaite, E. "Integrated evaluation of aerogenic pollution by air-transported heavy metals $(\mathrm{Pb}, \mathrm{Cd}, \mathrm{Ni}, \mathrm{Zn}, \mathrm{Mn}$ and $\mathrm{Cu})$ in the analysis of the main deposit media," Environmental Science and Pollution Research 21 (1), 299-313 (2014).

8. Raputa, V.F., Khodzher, T.V., Gorshkov, A.G., Koutzenogii, K.P. "Aerosol falls on snow cover on the outskirts of Siberian towns," Journal of Aerosol Science 29 (2), 807-808 (1998).

9. Yanchenko, N.I., Slutskii, S.L., Baranov, A.N., Verkhoturov, V.V. "Dynamics of fluoride atmospheric fallouts in the Baikal region," Russian Meteorology and Hydrology 40 (11), 766-771 (2015).

10. Shevchenko, V., Lisitzin, A., Vinogradova, A., Stein, R. "Heavy metals in aerosols over the seas of the Russian Arctic," Science of The Total Environment306(1-3), 11-25 (2003).

11. Saet, Yu.E., Revic, B.A., Janin, E.P., Smirnova, R.S. Environmental geochemistry, Nedra, Moscow, p 335 (1990)

12. Filimonenko, E.A., Lyapina, E.E., Talovskaya, A.V., Parygina, I.A., "Eco-geochemical peculiarities of mercury content in solid residue of snow in the industrial enterprises impacted areas of Tomsk," Proc. SPIE 4445, 929231 (2014).

13. Yazikov, E.G., Talovskaya, A.V., Zhornyak, L.V. Ecological and geochemical characteristic of the Tomsk city territory according to research of soil and snow, Tomsk, TPU, p 264 (2010).

14. Talovskaya, A.V., Filimonenko, E.A., Yazikov, E.G., Nadeina, L.V. "Contamination monitoring of snow cover in the vicinity of Tomsk petrochemical plant," Proc. SPIE 9292, 929236 (2014).

15. Arbuzov, S.I., Volostnov, A.V., Rikhvanov, L.P., Mezhibor, A.M., Ilenok, S.S. "Geochemistry of radioactive elements (U, Th) in coal and peat of northern Asia (Siberia, Russian Far East, Kazakhstan, and Mongolia)," International Journal of Coal Geology 86 (4), 318-328 (2011).

16. Talovskaya, A.V., Yazikov, E.G., Filimonenko, E.A. "Assessment of atmosphere pollution in urbanized areas of Tomsk region by the results of snow cover study," Environmental Geoscience 5, 408-417 (2014).

17. Rikhvanov, L.P., Yazikov, E.G., Baranovskaya, N.V., Zhornyak, L.V., Talovskaya, A.V.,Denisova, O.V., Sukhikh, Yu. I. "Environmental components status of the Tomsk region according to ecological and geochemical monitoring and human health," Health and Safety 1, 29-37 (2008).

18. Raputa, V.F., Talovskaya, A.V., Kokovkin, V.V., Yazikov, E.G. "Analysis of observations of the snow cover pollution by aerosol particles at the territory of Tomsk-city and Seversk-city environments," Atmospheric and Oceanic Optics 24 (1), 74-78 (2011). 